\title{
CUSTOMER SATISFACTION ANALYSIS OF SHARIA LAUNDRY PERFORMANCE IN SHARIA ECONOMIC PERSPECTIVE
}

\author{
Dwi Belia ${ }^{1}$, Putri Amalia Zubaedah ${ }^{2}$ \\ Institut Agama Islam Bunga Bangsa Cirebon ${ }^{1}$, IAIN Syekh Nurjati Cirebon ${ }^{2}$ \\ Email: dwibelia07@gmail.com ${ }^{1}$, putt.mafazha@gmail.com ${ }^{2}$
}

\begin{abstract}
Background: Sharia laundry is laundry which in its implementation uses sharia principles. Many factors affect the quality and operation of a business in the service sector, thereby affecting customer satisfaction or service users. Laundry Syariah is an option to increase customer satisfaction.

The purpose of the study: to determine the customer satisfaction of sharia laundry from an Islamic economic perspective, differences in sharia laundry in terms of customer satisfaction, and the marketing strategy used by sharia laundry in increasing customer satisfaction from a sharia perspective.

Research method: descriptive-analytical method. Sources of data used are primary data sources from data obtained by observing the place to be studied and other data which is the result of direct interviews from sources, namely Hijrah Laundry Syariah and in the form of collecting documentation from books, articles, journals, the internet and various other sources which are then analyzed through data reduction, data display, and verification to obtain.

The results of the study: Hijrah Laundry Syariah is a sharia-based laundry service located in Cirebon City. This laundry service has been established since 2019. Located precisely on Jalan Raya Pamengkang No. 14 Mundu District, Cirebon Regency. Viewed from the perspective of sharia economics, customer satisfaction for Hijrah sharia laundry follows the values and principles of sharia economics, which in the perspective of sharia economics customer satisfaction can be seen from five influencing factors, namely product quality, price, service quality, emotional factors, costs, and easy access to the product.

Conclusion: The results of this study conclude that Laundry Syariah guarantees customer satisfaction because of Islamic services and systems and ensures the welfare of managers and customers

Keywords: Customer Satisfaction, Privileges, Sharia Laundry
\end{abstract}

Diterima: 25-06-2021 Direvisi: 5-07-2021 Disetujui: 6-07-2021

\section{INTRODUCTION}

Customer satisfaction is one of the keys to creating relationships with customers that affect the long-term success of the company (Agnihotri et al., 2019). The level of customer satisfaction depends on the quality of the product or service, the level of quality according to customer expectations will result in a high level of satisfaction (Tao, 2014). Customer satisfaction is an important thing that every company must strive to be able to compete in the market to satisfy customer needs and desires (Solimun \& Fernandes, 2018).

Tjiptono in (Moh Saiful Bahri, 2020) suggests that customer satisfaction is an emotional response to an evaluation of the experience of consuming a product or service. Sumarwan Ujang also suggests that customer satisfaction and customer dissatisfaction are the impacts of comparisons between consumer expectations before purchase, which consumers get from the product that was purchased (Wardhani et al., 2015).

\begin{tabular}{ll}
\hline & Dwi Belia, Putri Amalia Zubaedah. (2021). Customer Satisfaction Analysis of Sharia Laundry \\
& Performance In Sharia Economic Perspective. Co-Value: Jurnal Ekonomi, Koperasi \\
How to cite: & Kewirausahaan Vol 12(2): $42-55$ \\
\hline E-ISSN: & https://greenpublisher.id/ \\
\hline Published by: &
\end{tabular}


Awareness in carrying out the teachings of Islam is increasing day by day among the Indonesian people, most of whom are Muslim. This awareness is not only visible in acts of worship that are directly related to Allah, but has also penetrated economic activities. This activity is often known as the word Sharia. In the banking world, for example, there has been a Sharia Bank. In other economic sectors, such as Islamic cooperatives, Islamic stocks, even in the world of washing and washing have also begun to appear Sharia Laundry. The world of laundry in Indonesia has appeared very much like mushrooms that grow in the rainy season. Indeed, this business world promises lucrative benefits if we do it with enthusiasm and patience. Compared to washing and washing businesses in general, the Sharia Laundry business provides better service, especially for Muslims. Because the service is focused on the purity of laundry, not just cleanliness, tidiness, and also the smell. So being holy is the differentiator from the business that has begun to give color to the midst of the many businesses in our society.

Community needs are increasingly diverse while human activities are getting denser from day today. In fulfilling daily needs, humans need clothing, food, and board. As we know that clothing needs are not only in the form of buying and wearing clothes, but also the need to care for and maintain them. And during dense and diverse human activities and activities sometimes they don't have enough time in terms of washing and cleaning clothes. So business in the field of clothing maintenance services or what we usually call laundry is one of the most needed human needs. At this time there are lots of laundries that open and provide various maintenance facilities clothes at increasingly competitive prices.

In a situation like this, of course, these laundry entrepreneurs may compete with other entrepreneurs. The level of competition in the business world requires every marketer to be able to carry out marketing activities more effectively and efficiently, one of which is by increasing customer satisfaction. Therefore, an entrepreneur must implement the right strategy to increase customer satisfaction.

A laundry service business is an ijarah business in the field of washing such as all types of textiles and their processed forms using water, washing soap, and washing machines. This business is very much in demand by business people because its prospects are considered beneficial for both producers and consumers (Bahri \& Naharia, 2019). The advantages of using laundry services do not always attract praise from consumers, sometimes some unprofessional laundry service businesses get complaints from their customers. The agreements made between the two parties (producers and consumers) cannot always run smoothly in the sense that each party is satisfied because sometimes some consumers often feel disadvantaged. After all, what they expect is far from satisfactory. If the laundry service user, in this case, the consumer does not receive the goods or services according to what was agreed upon, then the producer has defaulted, so that the consumer suffers a loss. If consumers experience losses and feel dissatisfied, they usually will no longer want to use the services at that place.

Many factors affect the quality and operation of a business in the service sector, thus affecting the satisfaction of customers or service users. For example, technical problems such as clothes that are worn out, clothes are still dirty, some are torn, confused, or even lost. This problem will certainly affect the level of customer satisfaction, even though customer satisfaction is very important for the continuity of a business or business. According to Philip Kotler and Kevin Lane Keller that Customer Satisfaction is the feeling of happy or disappointed someone who appears after comparing the performance (results) of the product thought about the expected performance (Kotler, n.d.) 
The washing process with thaharah is a washing process that not only provides neatness, smells, and is clean but has the value the sanctity of clothes so that they can be used for worship, while the kilo laundry has no sacred value and only washing by machine directly they also prioritize quantity and relatively cheaper prices. This thaharah process also has a principle of one machine for one consumer. Thaharah or holiness is a

recommendation in sharia as mentioned in the Al-qur'ans Surah Al-'Araf: 26:

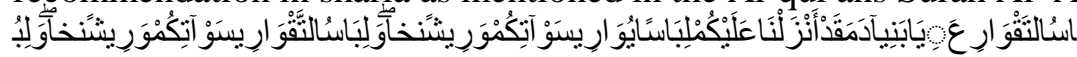

"O son of Adam, verily We have lowered to your clothes to cover your genitals and beautiful clothes for jewelry. And the clothes of piety are the best. This is part of the signs of Allah's power, hopefully, they will always remember." (Al-Quran translated)

Based on the verse, the recommendation to clean clothes is not only clean but must be clean from various impurities (holy) because the function of clothes is not only as a cover for genitalia or as jewelry but also for worship, therefore clothes must be clean and holy. Taharah is a recommendation from Sharia so that every laundry that uses the taharah process is known as sharia-based laundry.

Sharia laundry is a laundry that in its implementation uses sharia principles. This laundry is the same as conventional laundry, the difference is in the washing system and the system of using the contract in it. The contract referred to here is the contract of ijarah or lease. Leasing in Islamic law is known as ijarah which means wages, service rental, or reward. One form of human activity in muamalah is renting, contracting, selling services, and others. Harfiyah, al-ijarah means buying and selling benefits which is also the meaning of the term Syar'i. Al-ijarah can be interpreted as a contract of transfer of use rights over goods or services within a certain time limit, through the payment of rental wages, without being followed by a transfer of ownership of the goods. The existence of this sharia laundry is expected to be a choice for laundry service users to avoid the losses that often occur when using ordinary laundry services (Asmawati et al., 2018)

The sharia-based laundry service business is different from the laundry service business in general, such as kilogram laundry. The difference between the two laundry lies in the washing process and the price setting, sharia-based laundry uses washing with the thaharah process and the price offered is more expensive according to the quality offered (Bahri \& Naharia, 2019).

\section{RESEARCH METHODS}

The research approach that researchers will do is qualitative. This type of qualitative research in this research is a descriptive narrative conducted at Hijrah Laundry. Narrative descriptive research is research that is intended to collect information about the status of an existing symptom, namely the state of the symptoms according to what they are at the time the research was conducted without intending to make general or generalized conclusions.

The research was conducted at Hijrah Laundry Syariah which is located at Jalan Raya Pamengkang No. 14 Cirebon. In the data collection technique, various techniques were used in this study, namely interviews, observation, and documentation. The three techniques are used to obtain mutually supporting and complementary data and information regarding sharia-based car loan financing. Data analysis used in this study used data analysis techniques such as those proposed by Miles and Huberman, who stated that there were three kinds of qualitative data analysis activities, namely data reduction, data presentation, verification, and conclusions. 


\section{A. Research Results}

\section{RESULTS AND DISCUSSION}

\section{General Profile of Hijrah Laundry Sharia}

Hijrah Laundry Syariah is a Sharia-based laundry service located in Cirebon City. This laundry service has been established in 2019. It is located precisely at Jalan Raya Pamengkang No. 14 Mundu Subdistrict, Cirebon Regency. The owner is named Lusi Puspitasari. Previously he worked in Jakarta as a car salesman and wore short clothes without the hijab but what he was running did not know halal or not and starting from he stopped working and preferred to stay at home.

In 2017 she only wore a hijab and dressed in Muslim clothes until 2018 she only wore a veil until now. After being unemployed for a long time and only relying on a salary from her husband, she thought she wanted to open a business but could use the veil. Incidentally, he has a friend who works in the laundry and he often goes to his best friend's laundry place. In the end, he was inspired to open a laundry business but based on sharia. Starting from there he named his business with the name Hijrah Laundry Sharia because it was following the life of him who had now emigrated.

He started his business in 2019 in April after a year ago he opened a new branch in the Palimanan area which just opened on May 13, 2020. In running his business he provides a different concept from the laundry business in general. As the name implies, this laundry uses Islamic rules in washing clothes such as using running water during the washing process. It is not only the washing process that distinguishes Hijrah Laundry Syariah from other laundry businesses, namely, Hijrah Laundry Syariah always emphasizes good behavior for employees and customers.

The form of this company is a family business, so the initial capital is from the owner of the company, in this case, Mrs. Lusi Puspitasari herself. Starting in April 2019 with a high intention of capital and money of 5,500,000, Mrs. Lusi opened a small laundry business and at first opening, Ms. Lusi only received a gross income of 1000,000, - per month and one year later her turnover increased to a result of 9,000,000. - per month. But since the existence of the coronavirus, the turnover has decreased, now her income is only 3,000,000 to 4,000,000 million rupiahs per month. But Mrs. Lusi doesn't give up there, Mrs. Lusi continues to think and innovate to advance her laundry business. And until now, after a year ago he opened a new branch in the Palimanan area which just opened on May 13, 2020. In running his business, he provides a different concept from the laundry business in general.

In 2017 she only wore a hijab and dressed in Muslim clothes until 2018 she only wore a veil until now. After being unemployed for a long time and only relying on a salary from her husband, she thought she wanted to open a business but could use the veil. Incidentally, he has a friend who works in the laundry and he often goes to his best friend's laundry place. In the end, he was inspired to open a laundry business but based on sharia. Starting from there he named his business with the name Hijrah Laundry Sharia because it was following the life of him who had now emigrated.

Physical Condition of Islamic Laundry Hijrah:

- Business Name: Hijrah Laundry Sharia

- Laundry Owner: Lusi Puspitasari

- Business Products: Laundry Services

- Address: Jl. Raya Pamengkang No. 14 Mundu District, Cirebon Regency

- Vision: To become a laundry pioneer that is different in its washing which is known to the public as sharia laundry, oriented towards blessings and satisfaction, and produces good friendship, both to agents and customers. 
Number of Employees:

Pamengkang: 1 person

Palimanan: 1 person

Monthly Turnover: Before the existence of the coronavirus, sharia laundry migrations could reach a turnover of up to 9,000,000 million rupiahs per month. But since the existence of the coronavirus, the turnover has decreased, now the income is only $3,000,000$ to $4,000,000$ million rupiahs per month.

At Hijrah Laundry Syariah, there are facilities including:

a) Washing Machines: 2 units

b) Drying Machine: 1 unit

c) Steam Iron: 1 unit

d) Vacuum Cleaner: 1 unit

e) LPG Gas: 1 unit

Level of Customer Satisfaction Against Hijrah Laundry ShariaBased on the results of an interview with Mrs. Lusi Puspitasari as the Owner of Hijrah Laundry Sharia on Wednesday, May 20, 2020, at 09:00 WIB until finished at Hijrah Laundry Sharia which is addressed at Jl. Raya Pamengkang No. 14 Mundu District, Cirebon Regency regarding customer satisfaction at Hijrah Laundry Syariah Stating:

"What makes customers feel satisfied in using our services is First, in another laundry it does not prioritize holiness, but in sharia laundry hijrah prioritizes holiness because being holy is a legal requirement in praying. Second, in sharia laundry migration using an emotional approach, even amid an epidemic like this there are still loyal customers at our laundry because according to them our behavior is very polite, friendly, and familial and makes it easy for customers to wash their clothes because even at any time we are ready to pick up the laundry. Third, if something is damaged or something else, we are not free from responsibility and will replace it. Fourth, in this sharia laundry move, you can pay weekly or monthly according to the customer's ability, therefore they feel very happy and satisfied with our services. "

Meanwhile, according to Mba Ayu's explanation as an HijrahLaundry Syariah Employee on Wednesday, May 20, 2020, at 09:00 WIB until completion at Hijrah Laundry Syariah which is addressed at Jl. Raya Pamengkang No. 14 Mundu District, Cirebon Regency regarding customer satisfaction at Hijrah Laundry Syariah Stating:

"What makes customers feel satisfied in using this sharia laundry service, especially in the behavior of serving customers with courtesy, friendly, trustworthy and honest. The work is on time, neat, and smells long-lasting so that customers are satisfied and not disappointed."

According to the results of research interviews with Laundry Owners along with several Laundry Employees, it is concluded that customer satisfaction in this sharia laundry Hijrah is because the washing system prioritizes the sanctity of clothes so that it is legal for worship, laundry services to customers are very polite, friendly, trustworthy and honest and use emotional approaches such as kinship, then on time, neat, fragrant and durable laundry work, then also an affordable price and a payment system that can be weekly or monthly making it easier and easier for sharia laundry customers to migrate to sharia laundry.

\section{Service Distinction at Hijrah Laundry Sharia}

Based on the results of an interview with Mrs. Lusi Puspitasari as the Owner of Hijrah Laundry Sharia on Wednesday, May 20, 2020, at 09:00 WIB until finished at 
Hijrah Laundry Sharia which is addressed at Jl. Raya Pamengkang No. 14 Mundu District, Cirebon Regency regarding the distinction of customer satisfaction at Hijrah Laundry Syariah Stating:

"What distinguishes ordinary laundry from sharia laundry is in terms of behavior. In sharia laundry hijrah prioritizes behavior and we adopt polite, friendly, and familial behavior so that customers feel satisfied with what we treat customers. In terms of smell, it is different. use non-alcoholic perfume so that the fragrance is more durable and sharp. And here we are also very responsive if a customer's item is lost or our taper is responsible and does not underestimate it. Of course, washing it is different, there are still many laundries that do not have insight into how to wash them clean from dirt and unclean properly for Muslim clothes. Here we wash them one by one and do not use direct soap but rinse first using running water if it has just been put in the washing machine to continue washing. "

Meanwhile, according to Mba Ayu's explanation as a Sharia Laundry Hijrah Employee on Wednesday, May 20, 2020, at 09:00 WIB until finished at Hijrah Laundry Sharia which is addressed at Jl. Raya Pamengkang No. 14 Mundu District, Cirebon Regency regarding the distinction of customer satisfaction at Hijrah Laundry Syariah Stating:

"What distinguishes sharia laundry from the conventional laundry is in terms of behavior, sometimes it is not applied in the conventional laundry in being polite, friendly, and honest so that sometimes customers feel dissatisfied with the service. The difference with Islamic laundry, Islamic laundry prioritizes good behavior in accepting customers so that customers are satisfied and happy with their service. Besides, it is also different in terms of washing, if the sharia laundry is washing it with running water, washing the clothes is separated which are clean and which are unclean, the word is unclean in the sense that it smells like urine (small child rotten) and it is watered first and then washed using hands after cleaning. freshly washed using a washing machine different from conventional laundry the water does not flow and settles in the washing machine, sharia laundry uses non-alcoholic perfume while conventional laundry sometimes uses alcohol, of course in the packaging it is different if in sharia laundry after the clothes are finished drying it is immediately ironed and given perfume and then let it stand at a temperature so that the perfume has a long-lasting fragrance, different from conventional laundry, once it is ironed, the perfume is immediately packed."

And according to Ms. Suteni as a Hijrahlaundry customer who was interviewed on Wednesday, May 20, 2020, at 09:00 WIB until finished at Hijrah Laundry Syariah, which is addressed at Jl. Raya Pamengkang No. 14 Mundu District, Cirebon Regency regarding the distinction of customer satisfaction at Hijrah Laundry Syariah Stating:

"Laundry, In my opinion, Sharia and conventional laundry are very different, especially from how to wash them, the point is that in Sharia laundry, washing them uses Islamic fiqh rules, so besides being clean it is also holy, besides using non-alcoholic perfume so you avoid haram, so it's safe for worship use. "

According to the results of research interviews with laundry owners and several laundry employees and laundry customers, it is concluded that there is a very significant difference between Islamic laundry and conventional laundry in terms of customer satisfaction. Customer satisfaction in Islamic laundry is higher than in conventional laundry because there are several differences between the two.

\section{Marketing Strategy Used Sharia Laundry In Increasing Customer Satisfaction}

Based on the results of an interview with Mrs. Lusi Puspitasari as the Owner of 
Hijrah Laundry Sharia on Wednesday, May 20, 2020, at 09:00 WIB until finished at Hijrah Laundry Sharia which is addressed at Jl. Raya Pamengkang No. 14 Mundu District, Cirebon Regency regarding the distinction of customer satisfaction at Hijrah Laundry Syariah stated:

"Yes, of course, every laundry has the same marketing strategy, especially if it is clean, fragrant, and on time in the process so that it is attractive to customers and can increase customer satisfaction. But there is something different from another laundry, namely, here we prioritize holiness because we as Muslims if worship must be holy. After all, clean is not enough, so customers feel satisfied with our services. "

Mrs. Lusi Puspitasari also added:

"In Hijrah Sharia Laundry, there is always a $1 \mathrm{~kg}$ discount promo for new customers. And this is what is very interesting for customers, namely the sharia laundry migration, washing mukena, sarong, and other prayer tools, free of charge. Not only that, but the sharia laundry migration is also free to pick up and pick up laundry,"

Meanwhile, according to Mba Ayu's explanation as a Sharia Laundry Hijrah Employee on Wednesday, May 20, 2020, at 09:00 WIB until finished at Hijrah Laundry Sharia which is addressed at Jl. Raya Pamengkang No. 14 Mundu District, Cirebon Regency regarding customer satisfaction at Hijrah Laundry Syariah Stating:

"The strategy used by sharia laundry to increase customer satisfaction is to serve customers with polite, friendly, trustworthy, and honest behavior and in a timely and neat process. Apart from that, the laundry often holds promos, free shuttle, and free washing mukena. Koko clothes, prayer mats, and other prayer tools so that customers are satisfied and happy to use our services. "

Then according to Mrs. Suteni as a laundry Hijrah customer who was interviewed on Wednesday, May 20, 2020, at 09:00 WIB until it was finished at Hijrah Laundry Syariah which was addressed at Jl. Raya Pamengkang No. 14 Mundu District, Cirebon Regency regarding customer satisfaction at Hijrah Laundry Syariah Stating:

"The promos used for the hijrah laundry are very attractive and very Islamic, such as free washing promos for mukena, sarongs, and worship tools, there is also a $1 \mathrm{~kg}$ discount promo for new customers, then clothes that are washed clean, smell good, and are done on time according to the rules. fiqh, so that customers feel calm in using their clothes to worship "

According to the results of research interviews with Laundry Owners and several Laundry Employees and also laundry customers, it is concluded that the marketing strategy used by the laundry move is very attractive because it smells of Islam, such as free washing promos for mukena, sarong, and worship tools, then $1 \mathrm{~kg}$ discount promo for new customers and brands. Syariah, which ensures that clothes are washed according to fiqh principles, all of which are attractive marketing strategies in increasing customer satisfaction.

\section{B. Discussion}

How Sharia Laundry Customer Satisfaction in Islamic Economic Perspective

Viewed from the perspective of sharia economics, customer satisfaction Hijrah laundry sharia is following the values and principles of Islamic economics, which in the perspective of Islamic economics customer satisfaction can be seen from five factors that influence, namely product quality, price, service quality, emotional factors, costs, and convenience get the product.

\section{Product Quality}

Customers will be satisfied if after buying and using the product, the product quality is good. This product quality is a global dimension and there are at least five 
elements of product quality, namely performance, durability, features, consistency, and design (Anggun Nugroho, 2018)

The laundry business is a business in the service sector, which means that the product is washing services. The results of washing produced by Hijrah Laundry Sharia are the results of washing that is clean, fragrant, neat, and also clean from unclean. From this, in terms of product quality, Hijrah Laundry Sharia has produced good quality products g which can satisfy customers.

Price

For sensitive customers, usually low prices are an important source of satisfaction because they get high-value money. This component is very important for some companies who want to create customer satisfaction. In terms of the price of Hijrah Laundry Sharia, it is also very affordable and not burdensome, which only costs Rp. 7,000 per kilo for ordinary clothes. Of all the services offered by Hijrah Laundry Syariah, it has succeeded in making its customers feel very satisfied and giving a positive impression so that customers become regular customers and make this laundry continue to grow until now (Purwanto \& Nugroho, 2018)

\section{Quality of Service}

The quality of service or service quality is very dependent on three things, namely systems, technology, and people. This human factor contributes $70 \%$. No wonder that satisfaction with service quality is usually difficult to imitate. The quality of service in terms of humans, or this case, the employees at Hijrah Laundry Syariah are very good. Laundry owners teach their employees to always provide excellent service to every laundry customer (Belia, 2021)

Compared to washing and washing businesses in general, the Hijrah Sharia Laundry business provides better service, especially for Muslims. The service is focused on the sanctity of laundry, not just cleanliness, tidiness, and also its fragrance. This is the main attraction for Hijrah Laundry Sharia. The core of the Sharia Laundry Hijrah service product, whose market segment is the Muslim community, is not only clean from dirt but clean from dirt and unclean. This is what the owner of the Sharia Laundry Hijrah is very concerned about because Muslims are required to pray five times a day using clothes that are clean from dirt or najis (taharah), for all clothes worn during prayer.

\section{Emotional Factors}

Where customers feel satisfied with certain products even though they may be expensive, but they can cause a more satisfying feeling because of the emotional value provided by the brand of the product. The emotional value given by the brand from Hijrah Laundry Syariah is its consistency in keeping customers' clothes not only clean but also holy. For some people, maybe this is not an important thing. However, for Muslims, the sanctity of clothing is important. Muslims usually prefer to work with institutions/businesses that have a sharia brand. This is so that they don't have to feel anxious and worry anymore about halalness. Hijrah Laundry Syariah has implemented a washing system that complies with fiqh principles which produce clothes that are not only clean but also holy and can be used for worship. This has attracted the emotional value of customers and makes customers feel more satisfied to transact on Hijrah Laundry Sharia.

\section{Costs and ease of obtaining products}

Customers will feel more satisfied if the costs and products obtained are relatively easy, comfortable, and efficient in obtaining products or services.(Fan et al., 2020) As previously explained, Hijrah Laundry Syariah also sets a relatively cheap price of IDR 7,000 per kilogram. Hijrah Laundry Syariah also always makes it easy for customers to wash their clothes because at any time Hijrah Laundry Syariah is ready to pick up laundry 
to the customer's house. Another convenience is, in this sharia laundry move, you can pay weekly or monthly according to the customer's ability.

Therefore, in terms of cost and ease of getting the product, Hijrah Laundry Syariah has met the criteria very well so that customers are satisfied.(Alam et al., 2019) Islam teaches its people to help each other in matters of goodness another and Islam forbids mutual help in matters of evil. In the Koran surah al-Maidah (5): 02 its is explained:

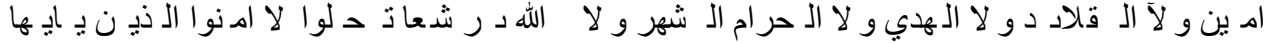

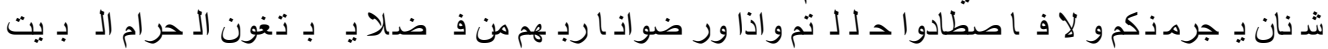

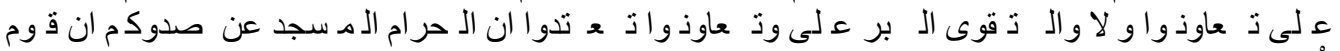

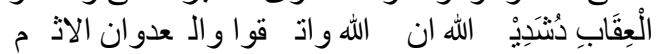

"O you who believe! Do not violate the syiars of the holiness of Allah, and do not (violate the honor) of the haram months, do not (interfere with) hadyu (sacrificial animals) and qala'id (marked sacrificial animals), and don't (anyway) disturb the people who visit Baitulharam; they seek the grace and pleasure of their Lord. But if you are have completed ihram, then you can hunt. Do not let (your) hatred towards a people because they hinder you from the Sacred Mosque, encouraging you to go beyond the limits (to them). And help one another in virtue and piety, and do not help one another in sin and enmity. Fear Allah, indeed, Allah is severe in punishment ". (Quran translated)

An economic transaction is certainly not free from sales and purchases which is described in the form of consumer (customer) satisfaction with the product or service obtained from the sale (Wagner \& Eidenmuller, 2019). Concerning the provision of consumer services, Islam has set out various ways to produce quality services for its customers (Zouari \& Abdelhedi, 2021). Achieving the best quality of service in an organization or company requires a solid Islamic management building foundation or also called total Islamic quality where the building foundation is sourced from the Quran and Hadith and can be formed if the following instruments are, namely:

- Must be based on strong patience

- Long-term commitment

- Continuous service quality improvement

- Cooperation and respect/respect for everyone

- Education and training.

Based on the exposure, it can be concluded that viewed in the perspective of sharia economy, customer satisfaction Hijrah sharia laundry following the values and principles of sharia economy which in sharia economic perspective customer satisfaction can be seen from five factors that affect product quality, price, service quality, emotional factors, cost and ease of getting the product. Customer satisfaction in Hijrah laundry sharia is because of its washing system that prioritizes the purity of clothing so it is legal to worship, laundry service to customers who are very polite, friendly, trustworthy, and honest and use emotional approaches such as family relationships, then timely and neat laundry work, fragrant and durable, then also the affordable price and it's a payment system that can be weekly or monthly thus facilitating and easing customers Hijrah laundry sharia.

\section{How Distingsi Laundry Syari'ah In Aspects Of Customer Satisfaction}

Compared to the washing business in general, the Shariah Laundry business provides a better service, especially for Muslims. The service is focused on the purity of laundry is not just cleanliness, cleanliness and also the fragrance only. So holy is the difference between the business that begins to take color amid the many businesses that exist in our society. This can be a unique attraction for business actors, especially for 
Muslim businessmen because in addition to worldly profits there can also be a place of da'wah for the Muslim community so that the benefits of the hereafter or rewards are obtained. So in other words, this kind of business provides a double benefit, which is the benefit of the afterlife (Wardhani et al., 2015)

The essence of laundry service products whose market segment is the Muslim community is not only clean from dirt but clean from dirt and feces. This is very important because Muslims are required to perform the five daily prayers by using clean clothes from dirt or najis (thaharah), for all the clothes that are worn at the time of prayer.

In terms of Syria 'thaharah is clean from najis good najis haqiqi, that is khubut (dirt) or najis hukmi, that is hadas. Najmi hukmi is najis found on some parts of the body that hinders the validity of prayer. These feces consists of small hadas that can be removed with ablution and large hadas that can be removed with a bath. The feces on clothes must be cleaned or purified before they can be used to perform prayers. Najis can be divided into four, namely light najis (Najis Mukhaffafah), Najis medium (Najis Mutawassithah), Najis heavy (Najis Mughalladah), and Najis that are forgiven (NajisMa'fu). (Wardhani et al., 2015)

Light feces (Mukhaffafah) is light feces.

Clothes that are contaminated, to purify them simply by splashing water on the affected area, should not be washed or washed. An example of this type of feces is the urine of a boy who has not eaten, in addition to his mother's milk.

Medium feces (Mutawassithah) is najis with medium levels.(Insani \& Andini, 2021)

Clothes that are exposed to feces should be cleaned by washing them thoroughly so that they do not lose their traces, smell, or taste. The feces that fall into this group include menstrual blood, pus, etc. This type of excrement can be divided into two, namely najis ainiah and najis hukmiah. Najis ainiah is uncleanness that is visible to the naked eye, while najis hukmiah is uncleanness that cannot be seen with the naked eye. Clothes that are exposed to feces ainiah must first be removed and then washed using running water. Clothes that are exposed to the feces of Ber Berkham really from dirt and feces like being exposed to dry alcohol, then just need to wash it with running water only.

Heavy feces (Mughalladah) is heavy feces.

Clothes or parts of the body that are affected by feces should be cleaned by washing as many as 7 times with water and one of them is mixed with soil. Included in this feces are feces that come from pigs or dogs.(Lin et al., 2020)

Forgiven feces (Ma'fu feces)

That is, feces that are difficult to recognize then can be forgiven and considered untouched by feces. Clothes that are exposed to feces are sacred even if they are not washed, for example; feet and ends of pants or gloves that are exposed to wet, and can not be observed feces or not.

Referring to these kinds of feces, then in the process of washing clothes, it is necessary to be careful so that the clothes are clean from dirt and feces. Hijrah Laundry Syariah, as the name implies is a Syariah-based laundry service business. Hijrah Laundry Syariah applies the system and principles of Sharia in running its laundromat business both in terms of service and the washing system. In terms of washing Sharia laundry with conventional laundry is very different, there are still many laundries that do not have insight into how to wash clean from dirt and unclean properly for Muslim clothes. In Sharia laundry, the way to wash it is not to use soap directly but to rinse first using running water if it has just been added to the washing machine to continue washing, Shariah laundry cleans it with running water, washing clothes is also separated which is clean and which is unclean, said najis in a sense like The smell of pesing (small child 
ompol) is watered first and then washed by hand after cleaning and then washed using a washing machine. Unlike conventional laundry, the water does not flow and settle in the washing machine, in sharia laundry it uses non-alcoholic perfume while conventional laundry sometimes uses alcohol, of course in the packaging it is different if in sharia laundry after clothes are dried it is immediately ironed and perfumed especially so that the perfume lasts longer than conventional laundry so it is ironed and given the perfume immediately packed.

In terms of Sharia laundry service with conventional laundry is also very different. In sharia laundry we prioritize behavior and we apply polite, friendly, and family behavior so that customers feel satisfied with what we do to customers. While in conventional laundry less polite, friendly, and honest behavior is applied so that sometimes customers feel dissatisfied with the service.(Wongkitrungrueng et al., 2019)

Based on this, it can be concluded that the separation of Sharia laundry with conventional laundry in terms of customer satisfaction lies in the washing system and service system. In terms of Hijrah Laundry Syariah, services apply Islamic values such as courtesy, friendliness, trust, and responsibility. Meanwhile, from the washing system, Hijrah Syariah Laundry implements the washing system following the rules and regulations in fiqh thaharah. That is, prioritizing purity as well as cleanliness.

\section{How Marketing Strategies Used by Shariah Laundry in Increasing Customer Satisfaction Shariah Economic Perspective}

Marketing activity (marketing) is the activity of channeling goods and services from the manufacturer to the hands of consumers. In this case, some basic questions include marketing activities (marketing); starting from what is marketed, who is marketing, to how goods and services are marketed through the activities of marketing functions such as purchasing, sales, transportation, and so on. Once the goods and services are distributed to the consumer, then the consumer will make several considerations, namely:

Attention means attention to the goods and services offered.

Through its Syariah brand, Hijrah Laundry Syariah has succeeded in attracting customers. As we know that Sharia-based laundry today is still very rare, so if there is a laundry that uses a Sharia brand then it will be very attractive to customers.

Interest, the emergence of interest to know more about the goods and services offered.

After successfully attracting customers with its Syariah brand, Hijrah Laundry Syariah has also made its customers more interested to know more about the washing system following the rules of jurisprudence. The owner or employee of Hijrah Laundry Syariah usually does not hesitate to explain to his customers the importance of washing clothes following the rules of jurisprudence to be pure from najis and valid for use in worship.

Desire, which is a desire that arises after being interested in the goods and services offered, the desire begins de pay attention and observe more deeply so you want to try the goods and services offered.

Hijrah Laundry Syariah with its sharia brand makes customers interested in finally examining more deeply the differences between conventional laundry and Sharia laundry which ultimately makes customers more interested and chooses to wash their clothes in Islamic laundry.

Action, which is an action that arises because it is ripe in its consideration of choosing goods and services that have been offered to be paid for, then consumed or 
used. With all the efforts and marketing strategies done by Hijrah Laundry Syariah, it has succeeded in making customers choose to use its services.

Satisfaction, after the goods, are consumed and used, further with the feeling of being satisfied or dissatisfied by consumers after using or using the goods and services previously purchased. This is a return (after sales / input / feedback) obtained by companies offering goods and services.

The marketing strategy used by Hijrah Laundry Syariah prioritizes customer satisfaction. Customers are the endpoint of the goal of marketing activities which are expected to buy goods and services with satisfaction. The term satisfactory (satisfaction) is the keyword for the success of marketing (marketing). Because if consumers are not satisfied with the goods and services purchased, then the purchase will never occur, the impact is that marketing will fail, so that it will result in losses for producers or companies that sell goods and services.

Apart from relying on its sharia brand, Hijrah Laundry Syariah also carries out several promotions to attract customers. Promotions made are also attractive because they have Islamic smells such as free washing promos for makes, sarongs, and prayer tools, then a $1 \mathrm{~kg}$ discount promo for new customers then the sharia brand which ensures that clothes are washed according to fiqh principles, all of which are attractive marketing strategies in increasing customer satisfaction

Marketing or marketing activities should be returned to their true characteristics, as was done by the Prophet. Therefore, Islamic marketing is important for marketers to penetrate the market. In Islam, there are nine kinds of ethics (akhlaq) that a salesperson must have, namely:

Have a spiritual personality (taqwa)

Good personality and sympathetic (shiddiq)

Be fair in business (al'adl)

Serve customers with humility (khitmah)

Always keep promises and not cheat (tahfif)

Honest and reliable (al amanah)

Don't like prejudice (su'udzon)

Don't like to badmouth (sharir)

Do not take bribes (riswah)

Rasulullah is a business pioneer who uses the principles of honesty and fair and healthy business transactions. He also did not hesitate to socialize his business principles in the form of education and firm statements to other businessmen. Since the 7th century, the Prophet taught his people how to trade properly. He highly prioritizes honest behavior, sincerity, professionalism, friendship, generosity.

Hijrah Laundry Syariah also tries to emulate the marketing strategy exemplified by the Prophet by applying good ethics (morals) in running his business. Owners and

employees always prioritize honest, sincere, professional, friendly, generous behavior as exemplified by the Prophet. This strategy has proven to have made the Hijrah Laundry Syariah customers are more satisfied

\section{CONCLUSION}

Based on the results of research that has been done regarding the analysis of customer satisfaction on the performance of Islamic laundry in the perspective of Islamic economics in Islamic laundry hijrah Jl. Raya Pamengkang, Mundu District, Cirebon 
Regency, it can be concluded that viewed from the perspective of sharia economics, customer satisfaction Hijrah laundry sharia is following the values and principles of Islamic economics, which in the perspective of sharia economics customer satisfaction can be seen from five factors that influence, namely product quality, price, service quality, emotional factors, costs and the ease of getting products. Customer satisfaction in this sharia laundry Hijrah is due to the washing system that prioritizes the sanctity of clothes so that it is legal for worship, laundry services to customers are very polite, friendly, trustworthy, and honest and use an emotional approach such as kinship, then proper laundry work time, neat, fragrant, and durable, then also an affordable price and a payment system that can be weekly or monthly making it easier and easier for sharia laundry Hijrah customers.

The distinction of Sharia laundry with conventional laundry in terms of customer satisfaction lies in the washing system and service system. From a service point of view, Sharia Laundry Hijrah applies Islamic values such as courtesy, friendliness, trustworthiness, and responsibility. Meanwhile, from the washing system, Hijrah Syariah Laundry implements a washing system that is following the rules and regulations in taharah fiqh. Namely, prioritizing purity in addition to cleanliness. The marketing strategy used by the laundry hijrah is very attractive because it smells of Islamic, such as free washing promos for mukenah, sarong, and worship tools, then a $1 \mathrm{~kg}$ discount promo for new customers, then the sharia brand that ensures clothes are washed according to the rules of fiqh, all of which are strategies Marketing is attractive in increasing customer satisfaction. Hijrah Laundry Syariah also tries to emulate the marketing strategy exemplified by the Prophet by applying good ethics (morals) in running his business. Owners and employees always prioritize honest, sincere, professional, friendly, generous behavior as exemplified by Rasulullah. This strategy has proven to have made Hijrah Laundry Syariah customers more satisfied.

In connection with the above research, the researchers provide suggestions that are expected to be taken into consideration for the Sharia Laundry Hijrah, Sharia Laundry Hijrah must always be consistent and continuous in increasing customer satisfaction with principles that are following the sharia economy, because it is consistent and continuous in improving customer satisfaction with rules that are following the sharia economy will create big changes in business, one of which is by increasing turnover and also a much more blessed business.

\section{BIBLIOGRAPHY}

Agnihotri, R., Yang, Z., \& Briggs, E. (2019). Salesperson time perspectives and customer willingness to pay more: roles of intraorganizational employee navigation, customer satisfaction, and firm innovation climate. Journal of Personal Selling \& Sales Management, 39(2), 138-158.

Alam, N., Gupta, L., \& Zameni, A. (2019). Cryptocurrency and Islamic Finance. In Fintech and Islamic Finance (pp. 99-118). Springer.

Asmawati, E. Y. S., Rosidin, U., \& Abdurrahman, A. (2018). Efektivitas Instrumen Asesmen Model Creative Problem Solving pada Pembelajaran Fisika Terhadap Kemampuan Berpikir Kritis Siswa. Jurnal Pendidikan Fisika, 6(2), 128-143.

Bahri, R., \& Naharia, N. H. (2019). Pengembangan Usaha Jasa Laundry dalam Meningkatkan Pendapatan Marginal rumah tangga dalam Perspektif Ekonomi Islam di Watampone (Studi Pada Octa Laundry). Jurnal Ilmiah Al-Tsarwah: Ilmu Ekonomi Dan Keuangan (Konvensional Dan Syariah), 1(2), 180-201.

Belia, D. (2021). Customer Satisfaction Analysis of Sharia Laundry Performance in Shara Economic Pierspective. Eduvest-Journal Of Universal Studies, 1(1), 30-43. 
Fan, X., Chai, Z., Deng, N., \& Dong, X. (2020). Adoption of augmented reality in online retailing and consumers' product attitude: A cognitive perspective. Journal of Retailing and Consumer Services, 53, 101986.

Insani, F. I., \& Andini, Z. (2021). Epistemology of Basic Concepts of Spiritual and Physical Thaharah: Analysis of The Benefits of Ablution Spiritually and Physically. Al-Insyiroh: Jurnal Studi Keislaman, 7(1), 26-43.

Lin, C.-F., Lin, M.-Y., Lin, C.-N., Chiou, M.-T., Chen, J.-W., Yang, K.-C., \& Wu, M.-C. (2020). Potential probiotic of Lactobacillus strains isolated from the intestinal tracts of pigs and feces of dogs with antibacterial activity against multidrug-resistant pathogenic bacteria. Archives of Microbiology, 202(7), 1849-1860.

Purwanto, A., \& Nugroho, A. (2018). Analisis Rancangan Teknologi Mobile Application Pada E-Booking Ruangan Untuk Kegiatan Ukm. Jurnal Teknologi Informasi Dan Komputer, 4(1), 66-70.

Solimun, S., \& Fernandes, A. A. R. (2018). The mediation effect of customer satisfaction in the relationship between service quality, service orientation, and marketing mix strategy to customer loyalty. Journal of Management Development.

Tao, F. (2014). Customer relationship management based on increasing customer satisfaction. International Journal of Business and Social Science, 5(5).

Wagner, G., \& Eidenmuller, H. (2019). Down by Algorithms: Siphoning Rents, Exploiting Biases, and Shaping Preferences: Regulating the Dark Side of Personalized Transactions. U. Chi. L. Rev., 86, 581.

Wardhani, W., Sumarwan, U., \& Yuliati, L. N. (2015). Pengaruh persepsi dan preferensi konsumen terhadap keputusan pembelian hunian Green Product. Jurnal Manajemen Dan Organisasi, 6(1), 45-63.

Wongkitrungrueng, A., Nuttavuthisit, K., Szabo-Douat, T., \& Sen, S. (2019). Customer deference to service providers in ordinary service encounters. Journal of Service Theory and Practice.

Zouari, G., \& Abdelhedi, M. (2021). Customer satisfaction in the digital era: evidence from Islamic banking. Journal of Innovation and Entrepreneurship, 10(1), 1-18.

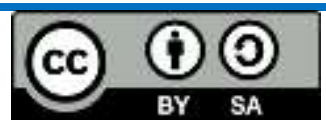

This work is licensed under a Creative Commons Attribution-ShareAlike 4.0 International License 